\title{
ÁRVORE NO DESERTO: UMA LEITURA ACROBÁTICA PARA UMA DRAMATURGIA DE CENA ${ }^{1}$
}

\section{ÁRVORE NO DESERTO: AN ACROBATIC READING FOR A SCENE DRAMATURGY}

\author{
José Guilherme Pereira Bergamasco ${ }^{2}$ \\ Veronica Fabrini Machado de Almeida ${ }^{3}$
}

\begin{abstract}
Resumo: Este texto abarca o processo de criação do espetáculo Árvore no Deserto (2011/2012), realizado pelo Grupo Ponte pra Lua da cidade de Campinas, SP. Reflete sobre um modo de leitura no qual o corpo esteja engajado em sua unidade psicofísica. Aborda a construção de uma linguagem híbrida no jogo entre o teatro, o circo, a dança, a música e o grafite. Discute a construção de uma dramaturgia cuja singularidade reside na articulação e contágio entre as linguagens e o uso da acrobacia e outros números circenses de risco como estratégia poética e narrativa.
\end{abstract}

Palavras-chave: Movimento; dramaturgia; acrobacia; circo.

\begin{abstract}
This text covers the creative process of Árvore no Deserto, (2011/2012), performed by the Ponte pra Lua Group, in the city of Campinas, SP. It reflects on a reading mode in which the body is engaged in its psychophysical unit. It approaches the construction of a hybrid language, playing between theater, circus, dance, music and the graffiti. It discusses the construction of a dramaturgy whose uniqueness lies in the articulation and contagion between languages and the use of acrobatics and other circus risk numbers as a poetic narrative strategy. Keywords: Movement; dramaturgy; acrobatics; circus.
\end{abstract}

\section{Uma forma singular de ler}

No silêncio e na intimidade da leitura o corpo inteiro se envolve. Às vezes com tranquilidade, outras com sobressaltos, suspiros, sorrisos, sustos, gargalhadas. E lágrimas. Relemos o que nos tocou para que o corpo sinta de novo. Às vezes a leitura é como um filme na nossa cabeça, outras como uma música, outras uma paisagem. Tudo que lemos flui de um modo singular entre a imaginação e a pele, entre a cabeça e o coração. A leitura é um circuito que, para o leitor atento e faminto, toma o corpo todo em sua integridade psicofísica.

Este texto propõe uma forma especial de leitura, uma forma muito física. Uma forma acrobática. Leitura feita sob a força da gravidade, presença invisível e constante de onde nascem expressões tão cotidianas como "cair em si", "tropeçar nas próprias pernas", "sinto-me leve como uma pluma", "tirei um peso dos ombros", "fulano é uma pessoa equilibrada". A força da gravidade é algo tão trivial que nos esquecemos dela, nos esquecemos do quanto ela é implacável. Generosa em seu acolhimento, voraz nas quedas, nos abismos, lúdica e amorosa no balanço. Laban ${ }^{4}$ constrói sua análise do movimento enquanto um entrelaçamento de peso, espaço, tempo e fluência. $\mathrm{O}$ fator peso é o primeiro fator de movimento com o qual nos damos conta em nossa existência corpórea. Percebemo-nos no mundo como ser que pesa. A sensação

\footnotetext{
${ }^{1}$ Texto baseado na dissertação de mestrado "Processo criativo da Árvore no Deserto: acrobacias na dramaturgia" defendida pelo primeiro autor sob a orientação da segunda autora, 2019, UNICAMP

${ }^{2}$ Ponto de Cultura NanoCirco, Campinas, SP, Brasil.

${ }^{3}$ Universidade Estadual de Campinas, Campinas, SP, Brasil.

${ }^{4}$ SCIALOM, Melina. Laban Plural: arte do movimento, pesquisa e genealogia da práxis de Rudolf Laban no Brasil. Summus Editorial, SP, 2017.
} 
de peso nos informa de nossa existência no mundo e o esforço para alcançar a verticalidade, na luta contra a gravidade, é um reflexo em torno do qual irão gestar-se inúmeras imagens arquetípicas. Ao excitar o fator peso, quer seja na nossa propriocepção ou numa leitura de movimento que fazemos - mesmo sem perceber que a fazemos - a acrobacia põe em questão nossa segurança de habitar um mundo sólido e real.

Quem nos propicia esse modo de leitura (e percepção) é o Grupo Ponte para a Lua e sua encenação da peça autoral Árvore no Deserto, na qual expressa suas ideias políticas e sociais, tendo a cena como momento de colocar em jogo essas ideias. Da dramaturgia à cena, as palavras e as ideias que elas engendram são transcriadas em corpos, em movimento, texturas, cores, som e ação.

Árvore no Deserto ${ }^{5}$ tem uma especificidade em termos de composição dramatúrgica na interação das acrobacias com as histórias dos personagens, especialmente em seus momentos de estopim, de modo a construir uma dramaturgia cinética e sinestésica. O estudo apresenta os caminhos na montagem da peça, descrevendo as dinâmicas de trabalho do grupo, o contexto e seleção dos textos utilizados na construção dramatúrgica, bem como a leitura das acrobacias como recurso motor expressivo de alta intensidade, capaz de proporcionar o acontecimento real em cena. A curva emotiva do personagem e da narrativa aliada a acrobacia é considerada determinante na dramaturgia da peça.

\section{O corpo do sujeito que lê}

Árvore no Deserto é uma peça teatral tecida com um compilado de materiais textuais, imagéticos e sonoros. Traz uma reflexão sobre as relações humanas nas grandes cidades. Concebida pelo grupo Ponte pra Lua ${ }^{6}$ entre 2011 e 2012, narra a vida dos personagens acentuando os momentos de ápice das curvas emotivas com acrobacias e outras performances circenses. Um determinado pensamento/estado emocional na vida de um personagem gera uma sensação como "estar sem chão", podendo ser camuflada num determinado momento por recursos de representação, para depois se manifestar performaticamente. É esse momento no qual as acrobacias e números circenses, como a pirofagia, malabares, tecido ou o trapézio em balanço se inserem como recurso motor expressivo de alta intensidade, gerando o acontecimento real na cena, ultrapassando a representação e assumindo o risco da performance como ação real, risco no aqui-agora da cena. Busca-se integrar a acrobacia não como efeito, mas como dramaturgia, como um trabalho sobre ações e a articulação de acontecimentos.

Árvore no Deserto estreou no final de 2012, depois de dois anos de trabalho intenso. Uma peça autoral criada coletivamente pelos acróbatas-atores, com a participação de músicos e da dança, fundamental no processo de percepção corporal e refinamento poético do movimento, ambos trabalhos necessários como contraponto para as exigências de alta intensidade requerida pela linguagem circense. Com este espetáculo híbrido, amalgamado com as linguagens do teatro, do circo, da dança e da música, o grupo procurou expressar suas ideias e impressões políticas e sociais, tendo a instância artística de uma arte viva e "ao vivo" como momento de encontro entre pessoas, entre subjetividades.

\footnotetext{
5 Processo criativo da Árvore no Deserto: acrobacias na dramaturgia, disponível em: <http://repositorio.unicamp.br/jspui/handle/REPOSIP/335208>.

${ }^{6} \mathrm{O}$ grupo Ponte pra Lua reúne atores-acrobatas desenvolvendo pesquisa sobre escrita teatral apoiada na performance acrobática, como nos espetáculos “O essencial é invisível aos olhos”, 2008, sob a orientação da Dra. Rosana Baptistella, "O Pequeno Príncipe”, 2009, direção de Rodrigo Matheus.
} 
Uma das primeiras e sábias decisões tomada pelo grupo foi a de optar por ter o ator Kuarahy Barretta Fellipe ${ }^{7}$ como diretor da peça. Em trabalhos de criação coletiva, com processos mais horizontais, muitas vezes se opta pela ausência dessa função. No entanto, aqui ela se fazia bastante necessária, oferecendo um ponto de convergência para a pluralidade de materiais. Cada artista trazia um texto, uma proposta acrobática, um rascunho de personagem, uma sequência de movimentos, músicas, desenhos. Fazia-se necessário um olhar externo para esse material a fim de propor articulações, exposição de personagens e conflito, construção de tensão, expectativas e relaxamento, potencializando a construção de sentido poético e sinestésico.

O cronograma de trabalho envolvia treinamento circense, prática em dança, jogos teatrais, estudo de mesa, improviso, ensaio e... a faxina do NanoCirco, espaço do onde os ensaios eram realizados. O trabalho teatral tem essa especificidade: se dá em coletivo, num determinado espaço que precisa ser cuidado. É um trabalho que não se "guarda" no papel ou numa gravação. Sua efemeridade, no entanto, vai aos poucos impregnando os corpos como uma segunda natureza. Por mais que cada ator tenha por hábito escrever seu diário de bordo, é nos nervos e na musculatura, na sensibilidade, na imaginação, na memória cinética que imaginário, personagens, narrativa e estilo vão se fazendo presentes. Era preciso aprender a escrever nessa outra língua híbrida e ela pedia uma caligrafia singular dos corpos, a composição cuidadosa de formas-gestos e suas articulações em frases, períodos e sobretudo o mais difícil: fazer poesia. $\mathrm{O}$ ator-acrobata devia manter-se atento as percepções, imagens e emoções geradas pelo trabalho, procurando integrar forma, sensação e expressão.

Depois de um esmerado trabalho de alongamento entendido como abertura para um corpo poroso, iniciava-se uma sequência de deslocamento passando pelos diversos apoios dos pés e mãos, seguido de rolamentos como cambalhotas, estrelas e piruetas. Assim, eram realizados giros de $360^{\circ}$ em cada um dos três planos de movimentação.

A seguir vinham os exercícios estáticos de equilíbrio: parada de três apoios, cabeça e mãos no chão e as pernas para cima; parada de mãos, só as mãos no chão e as pernas para cima; "aviãozinho", apenas um pé no chão e o corpo sustentado na horizontal como uma mesa. $\mathrm{Na}$ continuidade, exercícios de equilíbrio unidos às acrobacias básicas, resultando sequências acrobáticas no solo. Daí em diante, intensificando o treino acrobático, o risco aumentava. Com ajuda da lonja ${ }^{8}$ passou-se a treinar o rodante, a reversão, o flic-flac, o mortal à frente e o mortal para trás, até não precisar mais da lonja.

Pode parecer uma descrição unicamente técnica, mas atenção! Depois de tornar o corpo poroso e aberto à percepção e o estudo das formas e percepção com a dança ${ }^{9}$, o treino acrobático joga o tempo todo com o desafio do nosso centro de gravidade, desestruturando e reestruturando numa velocidade que o consciente não é capaz de captar, mas o inconsciente sim, ativando imagens mesmo sem nos darmos conta. Quem nunca despertou de súbito num sonho de queda? Temos a sensação nítida de que estamos caindo ou perdendo o equilíbrio. A ciência nomeia esse fenômeno como espasmo hípnico e atesta ser um fenômeno comum a maioria das pessoas, embora possa ser igualmente uma experiência aterradora. As causas são incertas, podendo ser desde estresse muscular, falta de magnésio, etc., mas o que interessa é o quanto essa é uma

\footnotetext{
${ }^{7}$ Kuarahy Barretta Fellipe, ator pela UNICAMP, em 2005, iniciou seus estudos em teatro na Escola de Atores do TUCA em São Paulo. Tem trabalhado, além de ator, como professor e diretor tanto no teatro como no circo.

${ }^{8}$ A lonja é um instrumento de segurança para o processo de ensino/aprendizagem das acrobacias, tipicamente circense, que consiste num cinto de segurança afivelado na cintura do acrobata, de onde saem duas cordas nas laterais, que passam por roldanas presas na cúpula do circo e voltam às mãos do lonjeiro - o operador da lonja, que, ao segurar a corda, garante a segurança do acrobata.

${ }^{9} \mathrm{O}$ trabalho de dança foi conduzido pela bailarina Tatiana Benone, bacharel em dança pela UNICAMP. Com ela, foram exploradas qualidades de movimentos e dinâmicas diferenciadas, colocando o corpo acrobático novamente em xeque, acrescentando ainda novas possibilidades perceptivas e expressivas.
} 
experiência comum e o poder da sensação, conferindo a ideia de queda um valor arquetípico mobilizador. A acrobacia e muitos números circenses tem esse apelo arquetípico da queda:

(...) as metáforas de queda são asseguradas, ao que parece, por um realismo psicológico inegável. Todas elas desenvolvem uma impressão psíquica que, em nosso inconsciente, deixa traços indeléveis: o medo de cair é um medo primitivo. Vamos reencontrá-lo como componente dos mais variados medos. (...) A queda dever ter todos os sentidos ao mesmo tempo: deve ser simultaneamente metáfora e realidade. (BACHELARD, 1990, p. 91-93).

Muitas vezes o almoço era coletivo e tinha como principal objetivo melhorar a alimentação do grupo, partindo do princípio básico do treinamento desportivo de ter como frentes de controle de treino: o estímulo, a suplementação e o repouso. Após o repouso, do almoço e de um café momento propício ao ócio criativo e ao devaneio - iniciavam-se as leituras de textos: peças teatrais, poemas, poesias, de fontes diversas, trazidos pelos integrantes do grupo. Importante sublinhar o estado de absorção desse material pois o corpo não é uma coisa que se pendura no armário depois de usar. O corpo somos nós, não nossa ferramenta. Corpo é sujeito. Estica, salta, gira, cai, come, sente, pensa e descansa. E é esse corpo em um estado singular que agora vai ler: peças, poemas, letras de música, contos, quadrinhos. As leituras foram gradativamente levando à seleção de alguns textos os quais, num processo de depuração realizado por meio de muitas leituras, desembocou na escolha dos textos principais da peça Árvore no Deserto: fragmentos de textos dramáticos de Harold Pinter, de uma peça de Luís Fonseca, entre outros.

Findo o primeiro ano de trabalho, o grupo alcançou uma corporeidade muito próxima àquele almejada para a peça, como se os corpos tivessem sido "alfabetizados" numa outra linguagem, com a eficiência e precisão acrobática dada pelo treinamento circense, as possibilidades de jogo e alteridade trazidos pelo teatro e o refinamento expressivo trazido pela dança. Mas não se tinha ainda nenhum esboço da peça. No segundo ano do projeto a dedicação foi dirigida para a composição do espetáculo. Foram mantidos o treinamento circense e os jogos teatrais, utilizando textos selecionados. O grupo experimentava diferentes dinâmicas de leitura, movidas pelos jogos, pelas acrobacias e movimentações, gerando configurações cênicas, esboços de sequencias narrativas. As cenas foram recebendo, ao longo do ano, os aparelhos aéreos de circo, de modo que as leituras e os personagens dos textos foram experimentando diferentes movimentações nos aparelhos, ainda sem definição, de acordo com a vontade e a capacidade que cada ator já havia desenvolvido em aparelhos específicos.

\section{A escuta, a leitura e o corpo - sujeito}

Com frequência, atrás da palavra falada está aquilo
que é sabido, mas calado. Meus personagens dizem
muito e nada mais sobre suas experiências, suas
aspirações, seus motivos e suas histórias. Entre a
minha falta de dados biográficos sobre eles e a
ambiguidade do que eles dizem, existe um território
que não é apenas digno de exploração, mas que é
obrigatório explorar.

Harold Pinter.

$\mathrm{Na}$ fala do diretor Kuarahy, pode-se vislumbrar como aconteceu a seleção dos textos para Árvore no deserto: 
Temos que descobrir qual é o material fundamental que está nos movendo e a gente acabou descobrindo que o Harold Pinter tinha vários textos que a gente podia utilizar, que tinham um universo de absurdo, um universo nonsense mas extremamente crítico, questionador, da maneira como a gente vive esse universo moderno, atual, urbano, que não é muito diferente hoje em dia da época que o Harold Pinter escreveu. Muitas coisas são exatamente as mesmas questões, elas se mantem., que é viver nesse capitalismo global, sufocado pela experiência das grandes cidades, e uma sensação de impotência e apatia muito grande (Entrevista com Kuarahy, 2018).

No período inicial do processo criativo, o grupo dedicava uma parte do dia de ensaio ao que chamamos em teatro de trabalho de mesa, uma leitura acurada, com vistas a destrinchar coletivamente o texto, quase como uma autópsia às avessas: procura-se o que torna um texto vivo. Quais as articulações e jogos de pensamento, quais os movimentos e ações contidos no texto? Quais as metáforas, as imagens materiais que lhe dão um certo temperamento, um sabor singular? Como cada pessoa da equipe (atores, músicos, cenógrafo, figurinista) se relaciona com o texto? O trabalho de mesa é um lugar de muitas perguntas, lugar no qual se busca atiçar as potencialidades estéticas, como comenta o encenador carioca Ricardo Kosovski,

Tradicionalmente, tem como ênfase a analise coletiva do texto. A leitura deste pressupõe um trabalho imaginário de situações dos enunciadores verbais: circunstâncias, diálogos, ação, personagens, ideia. Lugar de tonalização que esclareça a construção dramática, a apresentação da fábula, a emergência e resolução dos conflitos. A leitura em torno da mesa é feita buscando-se mentalmente a espacialização dos elementos dinâmicos do drama, para a colocação em relevo do esquema diretor da ação (KOSOVSKI, 2009, p. 62).

O trabalho de mesa em teatro propõe antes uma escuta do texto, uma escuta do material. O que esse material me pede? Como ele me afeta? Como se dão os fluxos entre o imaginário contido no texto, seus aspectos formais e a equipe de criação? Nesta fase do processo os textos eram trazidos intuitivamente pelos integrantes do grupo, de acordo com o gosto dos atores. As escolhas tinham uma baliza ampla: o espaço das grandes cidades, a solidão das grandes cidades, o que pode ser dito e o que deve ser calado, as desigualdades sociais, as pequenas e grandes violências. Importava também que o texto tocasse e movesse aquele que o escolheu. Porém, uma equipe grande resultou em um número igualmente grande de textos.

Kuarahy então sugere:

Vamos pegar esses textos, fazer um recorte neles, e conseguir desenvolver com os textos uma narrativa única onde cinco atores estão colocados em cada momento da peça num espaço específico numa linha temporal continua. Assumir que não vai ter metáfora, tempo voltando, e não é "isso é sonho" ou "aquilo é realidade", porque quando a gente começa um trabalho de colagem parece que vai realizar uma cena, então isso é subjetivo, onírico. A gente consegue assumir num certo ponto do processo que é um realismo do absurdo. É uma linha continua do tempo, onde tudo o que acontece na cena é realmente o que está acontecendo com as personagens e é um diálogo que vai para frente. A partir daí ficou muito mais fácil ir fazendo as colagens. A gente acabou fazendo alterações nos textos também para servir à nossa narrativa (Entrevista com Kuarahy, 2018). 
Ainda que apoiado na ideia geral de "colagem", ou seja, na articulação interna de fragmentos de diversos materiais literários, observa-se na fala do diretor um trabalho de tessitura dramatúrgica que, sem desconsiderar o lugar de origem de cada fragmento, preocupase com o movimento temporal de uma narrativa única. A leitura, discussão e seleção teceu fragmentos de diversos textos. O primeiro deles foi $O$ vento que vem, peça do dramaturgo e cineasta português Luís Fonseca, escrita para o Comuna-Teatro de Pesquisa ${ }^{10}$, de 2000 . Além de dramaturgo, Fonseca também traduziu peças de Stephen Berkoff, Caryl Churchill, Sam Shepard, David Mamet, Edward Albee, Samuel Beckett e Harold Pinter.

Harold Pinter (1930/2008), apareceu em diversas sugestões. Dramaturgo britânico, ator, diretor, poeta, roteirista foi também combativo ativista político de esquerda, destacando-se pela crítica ao capitalismo, na luta contra a pena de morte, a tortura, a guerra e a repressão. Sua denúncia aos Estados Unidos no discurso proferido como ganhador do Nobel de literatura, em 2005, é ainda extremamente atual, especialmente na situação na qual se encontra o Brasil e boa parte da América Latina:

Os crimes praticados pelos Estados Unidos são sistemáticos, constantes, cruéis, impiedosos, mas muito pouca gente toca no assunto. É por obra dos Estados Unidos que é assim. Eles manipulam o poder com extrema frieza no mundo todo fazendo-se passar por força universal do bem. (...) as ações dos Estados Unidos pelo mundo afora deixavam claro que eles haviam chegado à conclusão de que tinham carta branca para fazer o que bem entendessem. A invasão pura e simples de um Estado soberano nunca foi o método favorito dos Estados Unidos. De modo geral, eles sempre preferiram o que chamam de "conflito de baixa intensidade". Isto significa que milhares de pessoas morrem, porém mais lentamente do que se jogássemos uma bomba sobre elas (PINTER, 2005, p. 1).

Sua obra conjuga elementos existenciais, absurdos e metafísicos. Escreveu peças como Festa de Aniversário (The Birthday Party, 1957), O Porteiro (The Caretaker, 1959), Traição (Betrayal, 1978) e Volta ao Lar (Homecoming, 1965), que além de amplamente encenadas foram adaptadas para o cinema. De Harold Pinter ${ }^{11}$ foram selecionados alguns trechos e fragmentos de suas Cenas Curtas: "Monta-Cargas", "Ponto de ônibus" e "Estação Vitória".

No mesmo discurso citado acima, como ganhador discurso que levou o título de Arte, verdade e política, ele fala sobre seu processo de criação:

Não há distinções rígidas entre o que é real e o que é irreal, nem entre o que é verdadeiro e o que é falso. Uma coisa não é necessariamente falsa ou verdadeira, ela pode ser tanto verdadeira como falsa. [...] A verdade no teatro é sempre fugidia. Você nunca a encontra, realmente, mas a busca é compulsiva. A busca é claramente o que motiva o empreendimento, é a sua tarefa. (...) Muitas vezes me perguntam como minhas peças nascem. Não sei dizer. Nem posso resumir minhas peças, exceto dizendo que isso é o que aconteceu. Isso é o que eles disseram. Foi isso o que fizeram. A maior parte de minhas peças é engendrada por uma frase, uma palavra, uma imagem. A palavra dada é geralmente seguida por uma imagem. [...] A linguagem na arte permanece uma transição altamente ambígua,

\footnotetext{
${ }^{10}$ FONSECA, Luis. O Vento que vem. In: Cinco Peças Breves: Don Juan em Sua Companhia; Homem Mau; O Vento que Vem; A Portageira da Brisa, Passagem. Campo das Letras, 2002.

${ }^{11}$ PINTER, Harold. A Festa de Aniversário e O Monta-Cargas. Tradução: Alexandre Tenorio. São Paulo: José Olympio, 2016. PINTER, Harold. Teatro 2. Lisboa: Relógio d'água, 2002. PINTER, Harold. The Dwarfs: And nine revue sketches. Nova York: Dramatics Play Service, 1999. p. 35-36.
} 
uma areia movediça, um trampolim, um lago congelado que pode ceder sob os pés do autor a qualquer momento (PINTER, 2005, p. 1).

A caixa de areia ou eu era dois em meu quintal, foi outro material nesse tecido híbrido que compõe a peça. Uma história em quadrinhos de Lourenço Mutarelli ${ }^{12}$, autor que também transita entre as linguagens do cinema, do teatro e da literatura. Neste trabalho o próprio ato de contar uma história é desdobrado em metalinguagem: vemos nos quadrinhos os dilemas de criação do autor, seu alter-ego em desdobramentos na ficção, sua busca nas memórias de infância para entender quem ele é, revelando a própria busca da identidade como um processo de inventar-se.

A poesia de Bertolt Brecht ${ }^{13}$ também compôs a colagem de A Arvore no Deserto. Brecht (1898-1956) foi poeta, dramaturgo e encenador alemão. Com a ascensão do nazismo, passa diversos anos de sua vida no exílio, em vários países, escrevendo parte de sua obra nesses trânsitos. Alguns de seus textos mais conhecidos são: Mãe coragem e seus filhos (1941), Ascensão e Queda da cidade de Mahagonny (1930) e O Círculo de Giz Caucasiano (1948). Faleceu em 1956, em Berlim Oriental. Um dos grandes escritores da história do teatro, é autor e diretor de um teatro político, escrito com profundo conhecimento do espaço vivo da cena, em conexão com os atores, colaboradores, tradutores e, em especial, em profunda conexão com a música, a exemplo de sua parceria com Kurt Weill, Hanns Eisler e Hindemith. A árvore em fogo, foi o poema que inspirou a peça, como um duplo da árvore no deserto, como se a árvore do poema tivesse permanecido em sua grandeza de ruína, como testemunho entre os tempos, grafitada pelo ator logo na no Prólogo de Árvore no deserto, "Por um instante fica erguida contra o céu escuro/ E então/ Desaba".

Compôs ainda esse patchwork o Paradoxo do Pensamento Científico - Artista num Monólogo sobre o Universo, de José Javier Saéz Acuña ${ }^{14}$. Acuña, além de malabarista, músico e acrobata, é físico graduado na Universidade de Concepción (2003), doutor em Física pela UNICAMP (2009) e professor adjunto do Centro de Ciências Naturais e Humanas da Universidade Federal do ABC. Seu monólogo também transita sobre a instabilidade na construção de identidade, fluida e sempre ameaçada, quer frente as grandes cidades, quer frente a grandeza do universo. É justamente essa instabilidade que será acentuada pelo real desequilíbrio dos corpos em performance circense.

OPERADOR - Existe uma parte de mim que eu conheço e você conhece

Existe uma parte de mim que eu conheço e você não conhece

Existe uma parte de mim que você conhece e eu não conheço

Existe uma parte de mim que nem eu e nem você conhecemos.

\section{Acrobacias como dramaturgia}

O espetáculo Árvore no Deserto, utilizou-se de diferentes linguagens artísticas como o grafite e a poesia, a dança e o teatro físico, a música e, sobretudo a acrobacia enquanto estratégia de construção de uma dramaturgia performativa, no sentido do risco físico real que apresentam os números circenses. Pequenos e grandes riscos: a queda de uma bolinha que escapa da mão do

\footnotetext{
${ }^{12}$ MUTARELLI, Lourenço. A Caixa de Areia ou Eu Era Dois em Meu Quintal. São Paulo: Devir, 2005. Lourenço Mutarelli nasceu em São Paulo em 1964. É escritor, ator, dramaturgo e quadrinista brasileiro. Escreveu $O$ Cheiro do Ralo (2002), Diomedes - a trilogia do acidente (trilogia publicada entre 1999 e 2002), A Caixa de Areia ou Eu Era Dois em Meu Quintal (2006).

${ }^{13}$ BRECHT, Bertolt. Poemas (1913-1956). São Paulo: Editora 34, 2007.

${ }^{14}$ ACUÑA, Jose J. S. Paradoxo do Pensamento Científico - Artista num Monólogo sobre o Universo. Escrito em 14/02/2001 em Santiago do Chile e traduzido pelo autor em português em 07/10/2005. Não publicado.
} 
malabarista, corpos sobre corpos em saltos, aparos e quedas, o desabar deslizando pelo tecido, de cabeça para baixo, parando a poucos centímetros do chão, o corpo em voo no pendulo do trapézio.

Curioso paradoxo: uma situação ficcional, palavras e vidas alheias ao ator, guardadas em latência na forma escrita são dinamizadas pela imaginação na leitura e corporificadas pela cena. Na cena, a ficção vive, mas se dá a ver na dupla existência de ficção e atuação. Ela toma um corpo outro que não deixa de ser outro. Acordo, convenção: sabemos tratar-se de ator e personagem. Mas a acrobacia afirma um corpo real, em situação de risco real, risco incontestável, arquetípico, alheio àquela ficção, porém aqui, dela decorrente. Os microsobressaltos, sustos e desequilíbrios da leitura ganham escala máxima no corpo do ator em performance acrobática e não há mais separação entre ficção e real. Na plateia, nossos neurônios espelhos nos fazem sentir na nossa carne a realidade da ficção e a ficção da realidade.

Os neurônios espelho desempenham uma função crucial para o comportamento humano. Eles são ativados quando alguém observa uma ação de outra pessoa. O mais impressionante é o fato desse espelhamento não depender obrigatoriamente da nossa memória. Se alguém faz um movimento corporal complexo que nunca realizamos antes, os nossos neurônios-espelho identificam no nosso sistema corporal os mecanismos proprioceptivos e musculares correspondentes e tendemos a imitar, inconscientemente, aquilo que observamos, ouvimos ou percebemos de alguma forma (GAWYSZEWSKI; LAMEIRA; PEREIRA, 2006, p. 129).

Foi no tecer desta peculiar dramaturgia acrobática que o grupo foi gestando uma linguagem híbrida na qual a atuação e a acrobacia dialogam, sobrepõem-se e interagem de forma a potencializar as intenções, os objetivos da cena, com o intuito de criar uma dramaturgia de movimento de caráter poético e não literal. Ao contrário do que afirma Pencenat (2009), o grupo não trabalhou com a noção de "performance atlética" versus "performance de ator", mas sim com uma composição híbrida que não esconde suas fissuras.

Juntar os personagens aos aparelhos circenses e às acrobacias foi um desafio para o processo criativo do espetáculo, pois muitas vezes o corpo que executava uma técnica acrobática não era o mesmo corpo do personagem. O desafio de manter certa verossimilhança ampliou o entendimento e a própria performance da acrobacia e dos aparelhos como trapézio e tecido, pois fez-se necessário tornar crível que um determinado personagem frágil ou mesmo exausto fosse capaz de uma movimentação incrível, porém, sem derrubar sua "máscara de personagem". À princípio, isso poderia excluir a acrobacia de uma cena ou de um personagem da peça. Mas aceitar esse desafio propiciou um mergulho mais profundo no coração de cada acrobacia, buscando associar a sensação de cada uma delas, tencionando ao máximo a exigência do sucesso e o medo do fracasso, matizando cada uma delas com maior ou menor energia, mais ou menos cor, mais ou menos dinâmica de impacto. A acrobacia passou a ser utilizada pelo grupo para transformar os estados do ator e criar a energia da cena. A percepção de que estas ondas poderiam entrar em ressonância, proveniente do trabalho com a dança, definiu a ordem das acrobacias durante a peça, norteando as sequências das cenas e trazendo aos textos uma ordem dramatúrgica. Deste modo, cada personagem teria suas acrobacias como ponto de fuga para a expressão de suas angústias e emoções vivenciadas em meio aos conflitos registrados em uma metrópole, tais como, trânsito, chuva, alagamento, acidentes etc., além dos embates sociais de classe, de gênero, de geração e de poder.

A inserção das acrobacias é circunstancial, uma vez que elas aparecem em uma determinada situação em função da cena, mas, ao inseri-las, elas passam a ser um fator de transformação da própria circunstância que vai mexer no personagem, mudando sua trajetória 
no espaço e sua relação com o meio, e transformando radicalmente a atuação, por se tratar de uma outra linguagem a qual exige outro tipo de empenho e altera o bios do ator.

A intensão guia de Árvore foi transmitir ao público a mensagem, ou melhor a sensação de que as coisas não estão em seu equilíbrio, que a desigualdade e injustiça social gera violência, que dinheiro gera aprisionamento num sistema injusto e desumano, enfim, de que "as coisas não vão bem". No conflito entre voo e queda, o modo de utilização da acrobacia na dramaturgia apontou para possibilidade de libertação via transformações internas de cada indivíduo em suas escolhas, pensamentos e ações no seu cotidiano. Selando esse pensamento, o espetáculo encerrava com o número de pirofagia "Fogo na Babilônia", reduzindo tudo a cinzas, como no poema de Brecht, para que algum Fenix renasça.

\section{O desenvolvimento das cenas do espetáculo Árvore no Deserto}

\section{Prólogo: Grafite}

Um jovem grafita um deserto em um painel que representa um tapume de construção de uma grande cidade. Ao terminar a pintura, dança em frente à sua pintura e declama um poema como uma espécie de assinatura da obra. Ao terminar o poema, ele sai de cena e se dirige à mesa de luz, uma vez que ele exerce também a função de iluminador, um iluminador que irá "pintar" a cena.

Antes de entrarem os atores da peça, os três músicos se posicionam; um deles vai, em cenas posteriores, atuar como um dos personagens: o músico. Depois dos músicos, entram em cena o Sócio Principal, a Mulher, o Operador e o Taxista.

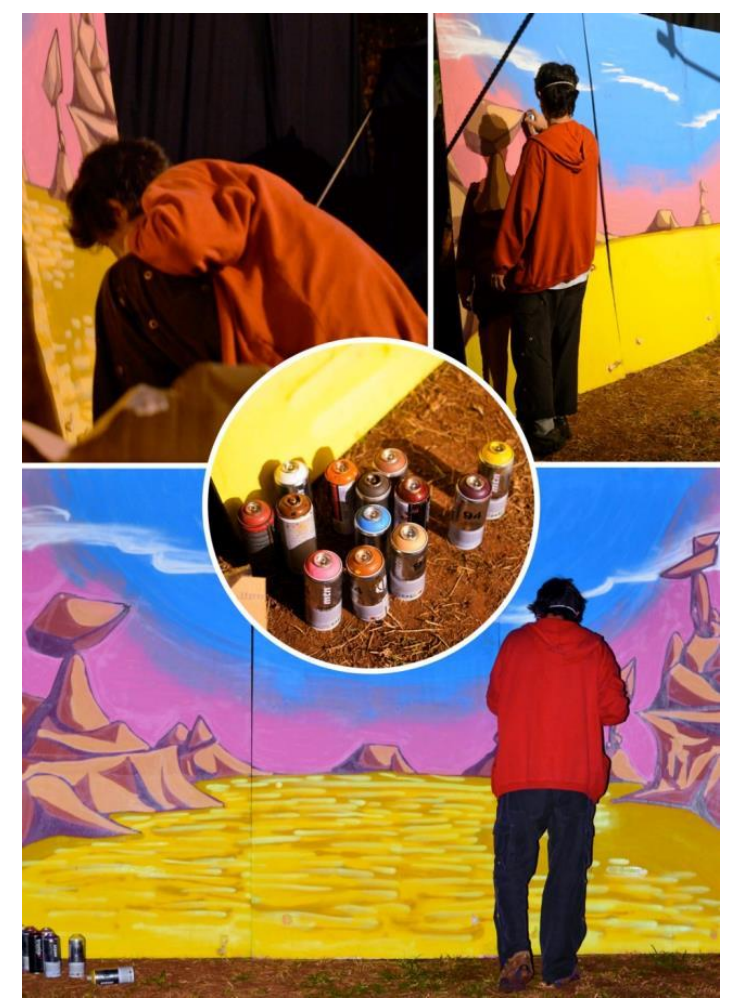

Figura 1 - Grafite. Fonte: acervo do Ponte pra Lua. Foto: Rodrigo Torii. Edição: Tobias Rezende 


\section{Cena 1: Deserto}

Operador e o Taxista se sentam no carro e no percurso para o trabalho iniciam um diálogo. São velhos amigos que trabalham em uma mesma empresa de rádio-táxi - um como taxista e outro como operador na central. O primeiro é mais novo e está insatisfeito com a vida na cidade: trânsito, violência, desigualdade social. O Operador, mais velho, mesmo cansado da mesmice do trabalho, tem uma posição mais acomodada, gastando seu tempo contando histórias de amor por ele vividas. Papo vai, papo vem, a conversa leva a uma discussão banal sobre diferentes visões de mundo, com ambos se agredindo verbalmente. A saída de ambos do carro na chegada ao trabalho, com a retirada do carro do meio da cena por eles, marca o final da primeira cena.

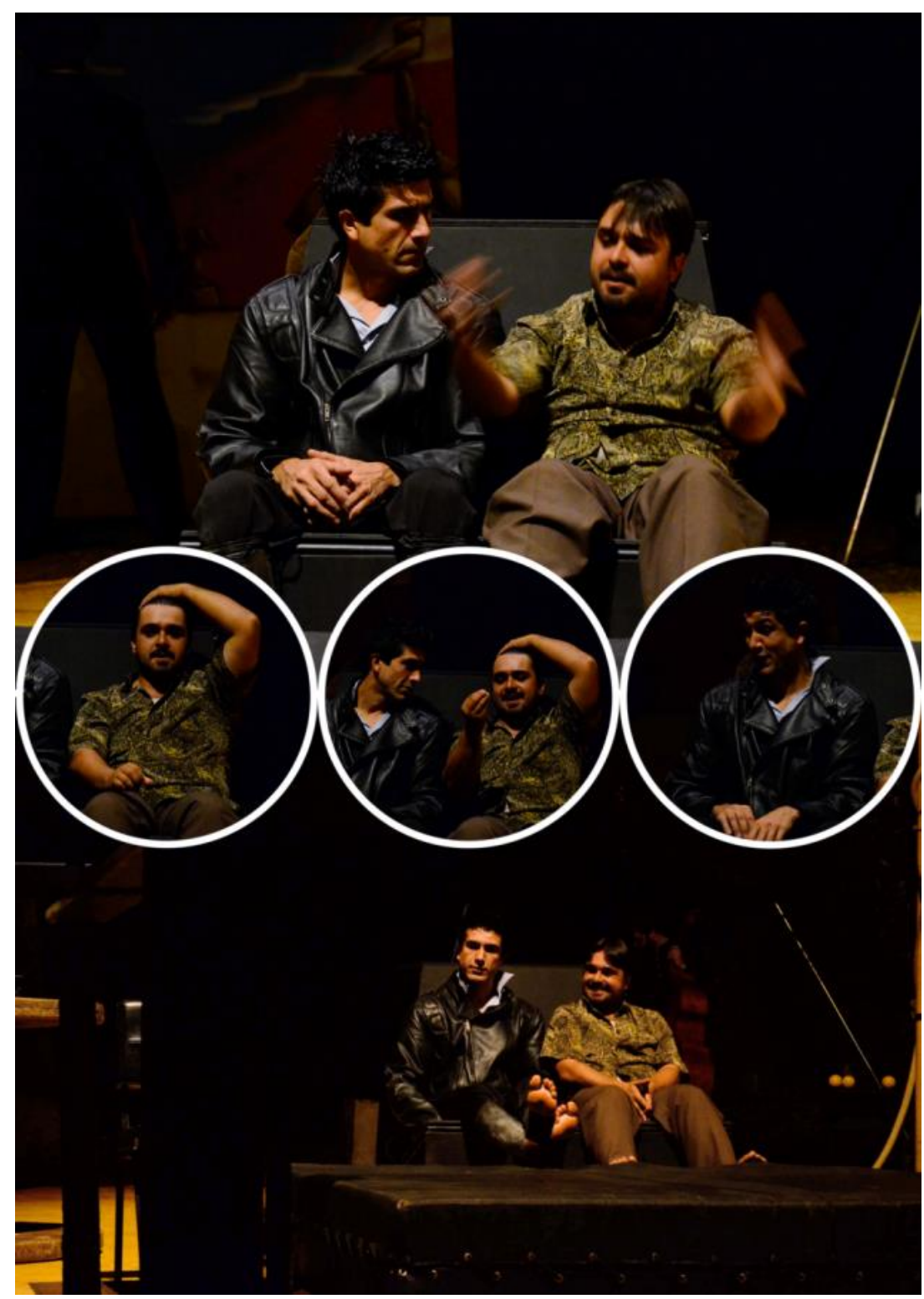

Figura 2 - Deserto. Fonte: Acervo do Ponte pra Lua. Foto: Rodrigo Torii. Edição: Tobias Rezende. 


\section{Cena 2: Monta-Cargas}

O Sócio Principal e o Músico fazem o reconhecimento do local onde irão executar um serviço escuso, num pequeno quarto escuro no porão de um estabelecimento abandonado. São dois matadores de aluguel. Jogam conversa fora lembrando serviços anteriores, pulverizando lamentos do desconforto das condições de sua profissão. O Músico lamenta nunca ter conseguido planejar seu serviço por se tratar de uma situação de risco, clandestina, da qual só tomam conhecimento alguns minutos antes de sua execução. As informações sobre o trabalho do dia começam lentamente a chegar por meio de códigos em bilhetes trazidos por um montacargas, representado pela Mulher no tecido acrobático. Após momentos de tensão, ambos percebem que a vítima desta vez é o próprio Músico, talvez por ter falado demais sobre o último serviço ou por sempre perguntar demais sobre a organização. O Sócio Principal decide não executar o serviço e ambos fogem.
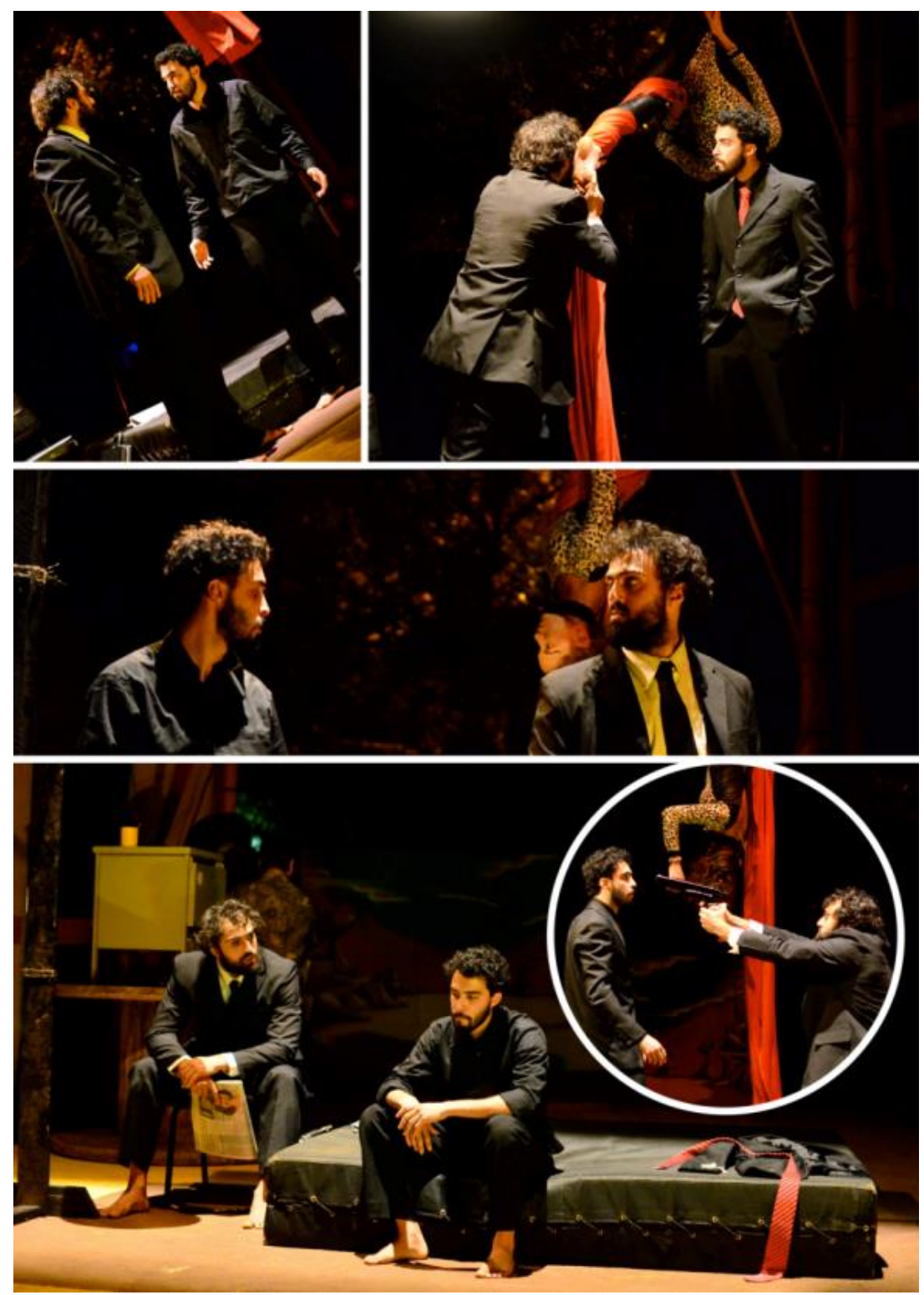

Figura 3 - Monta-cargas. Fonte: Acervo do Ponte pra Lua. Foto: Rodrigo Torii. Edição: Tobias Rezende. 


\section{Cena 3: Ponto de Ônibus}

Num ponto de ônibus, encontram-se os dois matadores de aluguel: o Sócio Principal e o Músico, o Operador da central de táxi e a Mulher.

A inquietude dos dois primeiros, em decorrência da fuga, revolta a mulher, que se sente oprimida, iniciando um discurso em defesa das mulheres, em razão de não ter obtido deles resposta a uma pergunta, além de eles terem tomado seu lugar na fila do ônibus. A Mulher recorre ao Operador da central de táxi para que o mesmo a ajude a denunciar os outros dois, mas este chama o primeiro táxi que passa e vai embora. Ao perceberem que a Mulher insistia em denunciá-los, os dois matadores fogem sorrateiramente, ficando ao final da cena somente a Mulher. Dá-se o encontro do Taxista com a Mulher: ela falando sozinha, o que nas entrelinhas dá a entender sua vontade de tirar a própria vida. O Taxista se aproxima iniciam um diálogo que vai se transformando em paixão, expressa por meio de uma dança culminando em uma sequência de tecido acrobático e trapézio fixo.

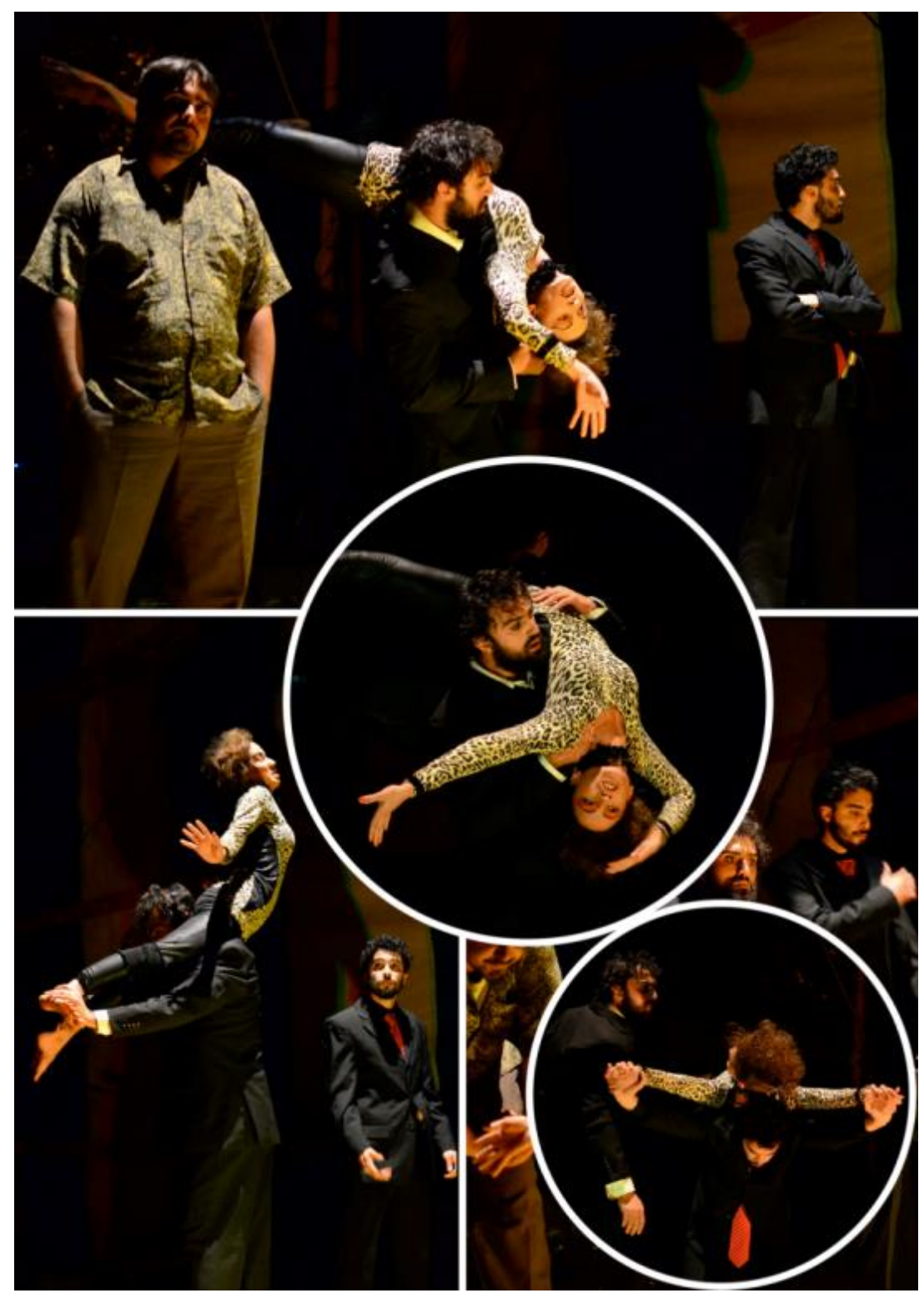

Figura 4 - Ponto de Ônibus. Fonte: Acervo do Ponte pra Lua. Foto: Rodrigo Torii. Edição: Tobias Rezende. 


\section{Cena 4: Estação Vitória}

Sequência de trapézio em balanço, interrompida por uma chamada da central de táxi. O Operador tenta contato com o taxista para a realização de um serviço específico, provavelmente ligado a máfia para quem trabalham os matadores de aluguel, mas o Taxista se nega a executar a corrida, por se encontrar no táxi com a Mulher pela qual está apaixonado, planejando uma fuga com o táxi da empresa. Em meio a discussão entre Taxista e Operador, que insiste que se trata de um serviço com ótima remuneração, o Taxista revela seu plano de fuga.

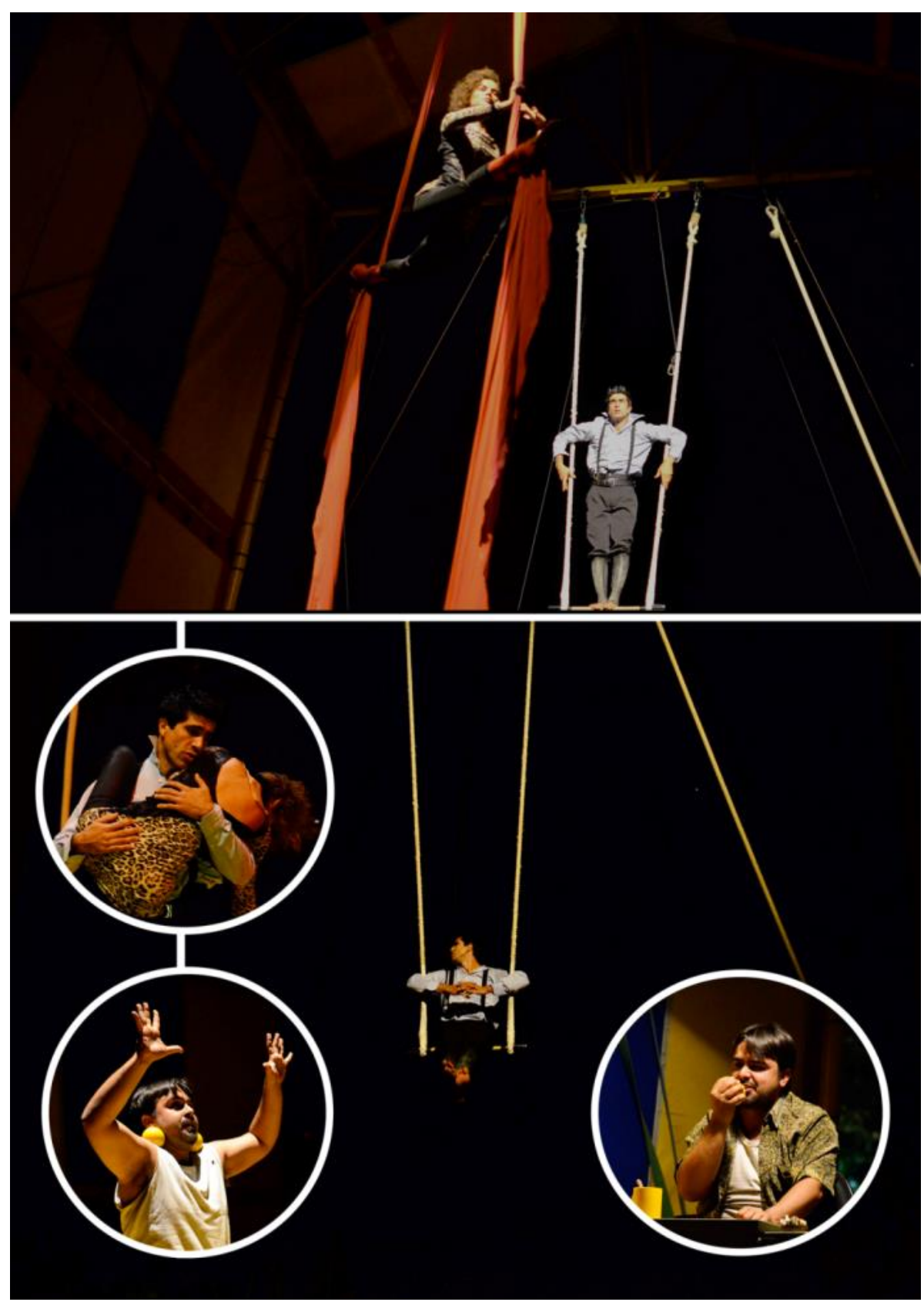

Figura 5 - Estação Vitória. Fonte: Acervo do Ponte pra Lua. Foto: Rodrigo Torii. Edição: Tobias Rezende. 


\section{Cena 5: Fogo na Babilônia}

O Operador, que não aguenta mais a pressão do trabalho, deixa seu posto e executa uma sequência de malabares, marcando o início da dança final com a participação de todos os personagens da peça. A dança termina com o "Fogo na Babilônia", espetáculo pirofágico que marca o final da peça.
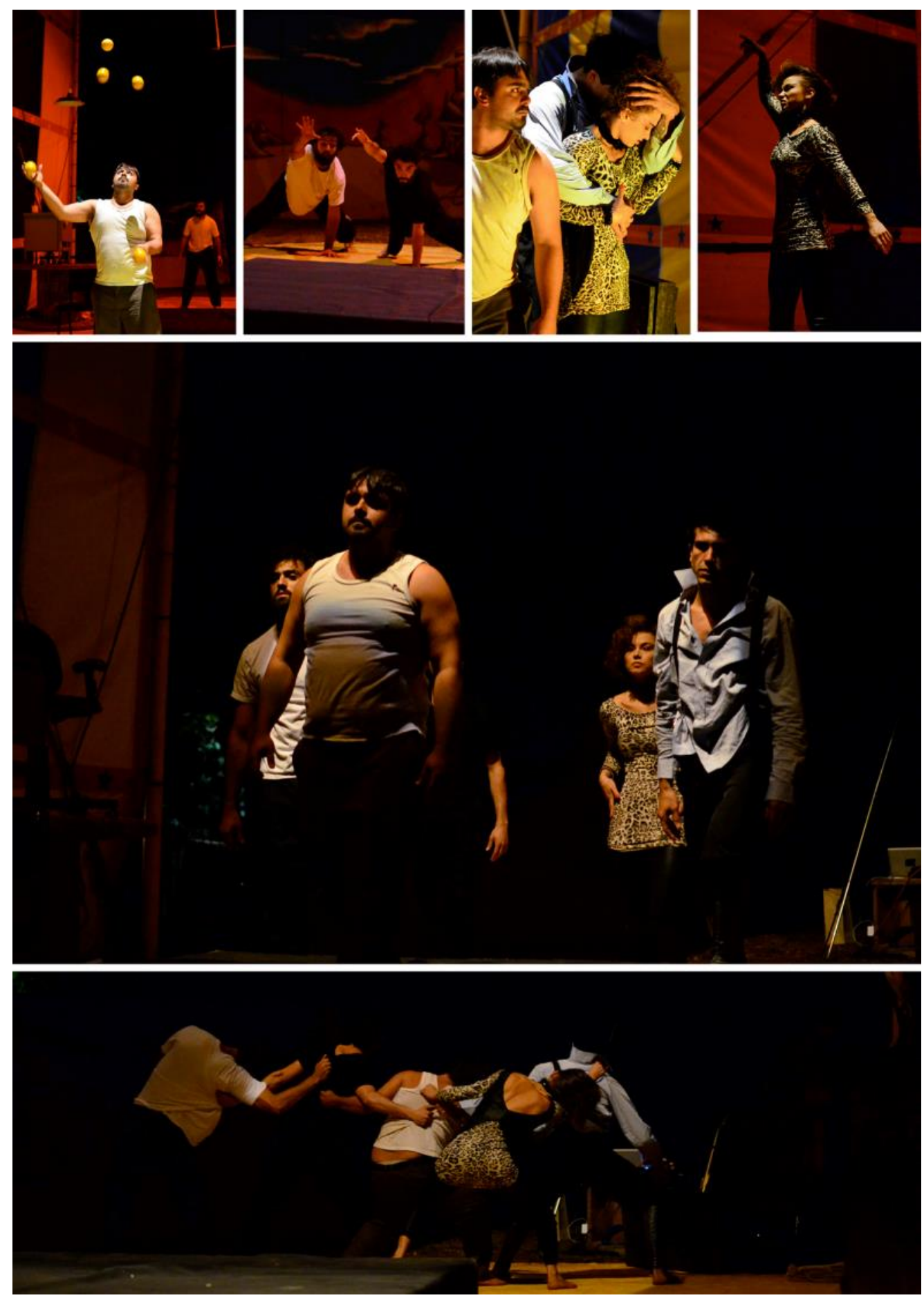

Figura 6 - Fogo na Babilônia. Fonte: Acervo do Ponte pra Lua. Foto: Rodrigo Torii. Edição: Tobias Rezende. 

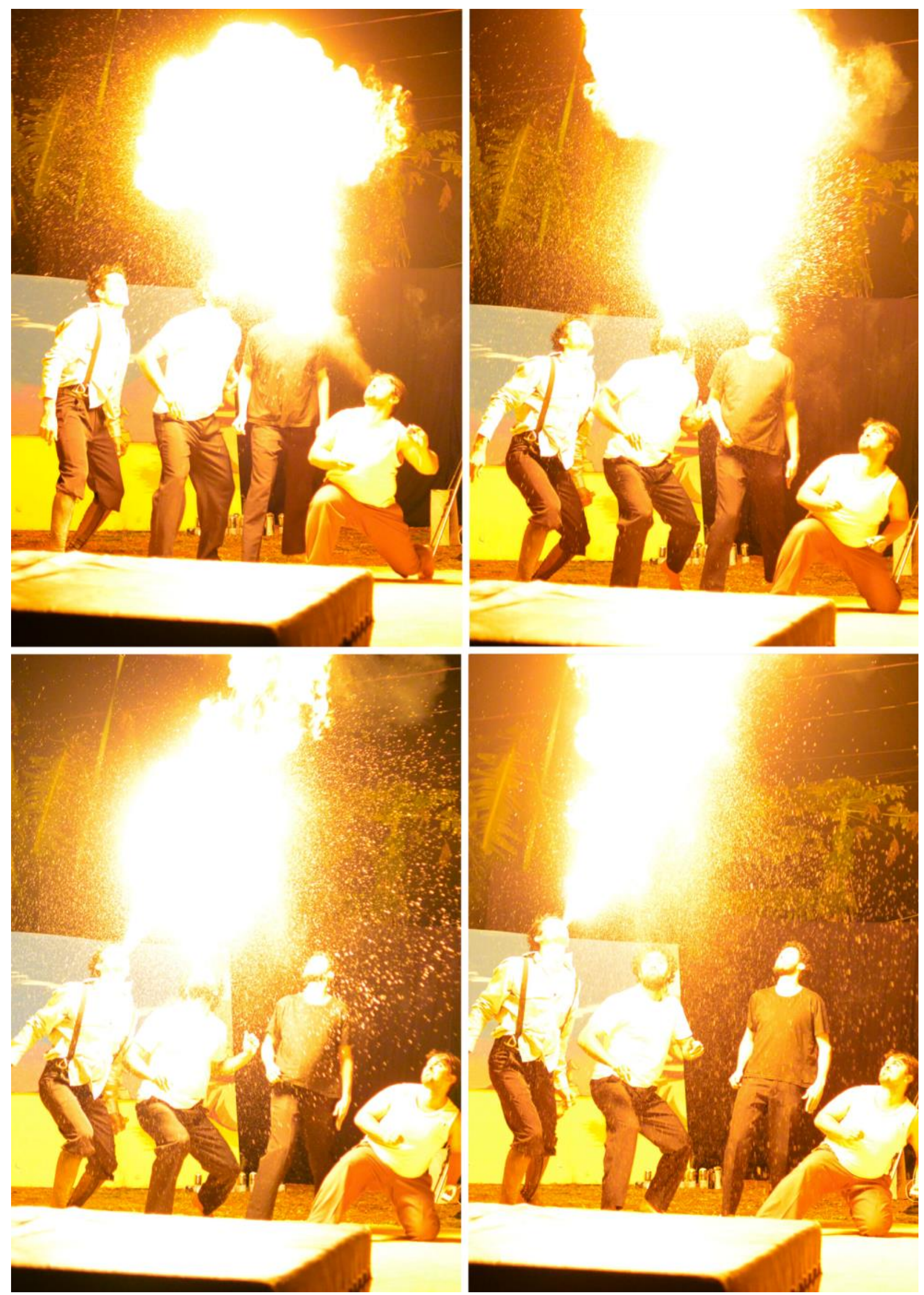

Figura 7 - Pirofagia. Fonte: Acervo do Ponte pra Lua. Foto: Rodrigo Torii. Edição: Tobias Rezende 


\section{Da leitura acrobática à ideia de outras quedas}

Ao fazer uma crítica contundente às grandes metrópoles, Árvore no Deserto vem denunciar as condutas usurpadoras dos direitos humanos, dos direitos da Natureza, aviltados e destruídos pela ganância neoliberal, consumista, pesada. Aqui compreende-se o Teatro como atitude política catalizadora e agente de difusão de pensamentos e sentimentos revolucionários, avesso aos princípios dos meios de vida da sociedade moderna, pautada no consumo exacerbado, regida pelo capital neoliberal gerador de desequilíbrio e injustiça, que oprime as reflexões e ações sociais sustentáveis, saudáveis, como uma tarde no Circo, que se apresenta sempre com brilho, calor, emoção e alegria para sobreviver, sem medo de ser feliz. Que caiam as bastilhas, as bolsas e as tiranias para que possamos renascer das cinzas e voar!

\section{Referências}

ACUÑA, Jose J. S. Paradoxo do Pensamento Científico - Artista num Monólogo sobre o Universo. Escrito em 14/02/2001 em Santiago do Chile e traduzido pelo autor em português em 07/10/2005. Não publicado.

ARAUJO et al. Estudo de Caso. 2008. Dissertação (Mestrado em Educação). Instituto de Educação e Psicologia, Universidade do Minho, Portugal, 2008.

BERGAMASCO, J. G. P. Processo criativo da Árvore no Deserto: acrobacias na dramaturgia. 2019. Mestrado (dissertação). Instituto de Artes, Universidade Estadual de Campinas, Campinas, 2019. Disponível em: 〈http://repositorio.unicamp.br/jspui/handle/REPOSIP/335208>.

BACHELARD, Gaston. O Ar e os Sonhos. São Paulo: Martins Fontes, 1990.

BRECHT, Bertolt. Poemas (1913-1956). São Paulo: Editora 34, 2007.

FONSECA, Luis. O Vento que vem. In: . Cinco Peças Breves: Don Juan em Sua Companhia; Homem Mau; O Vento que Vem; A Portageira da Brisa, Passagem. Porto (Portugal): Campo das Letras, 2002.

GAWYSZEWSKI, L. G.; LAMEIRA, A. P.; PEREIRA Jr., A. Neurônios Espelho. Psicologia USP, São Paulo, v. 17, n. 4, p. 123-133, 2006. Disponível em: <http://www.scielo.br/pdf/pusp/v17n4/v17n4a07.pdf $>$.

KOSOVSKI, Ricardo. Da mesa para a cena. Olhares, n. 1, 2009. p. 62-65.

MUTARELLI, Lourenço. A Caixa de Areia ou Eu Era Dois em Meu Quintal. São Paulo: Devir, 2005.

PENCENAT, Corine. Atleta, ator, artista? In: WALLON, E. (Org.) O circo no risco da arte. Belo Horizonte: Autêntica Editora, 2009.

PINTER, Harold. A Festa de Aniversário e O Monta-Cargas. Tradução: Alexandre Tenorio. São Paulo: José Olympio, 2016.

PINTER, Harold. Teatro 2. Lisboa: Relógio d'água, 2002. 
PINTER, Harold. The Dwarfs: And nine revue sketches. Nova York: Dramatics Play Service, 1999. p. 35-36.

PINTER, Harold. Arte, verdade e política, Discurso na entrega do Nobel de literatura, 2005. Disponível em: <https://cultura.estadao.com.br/noticias/geral,leia-a-integra-do-discurso-dopremio-nobel-harold-pinter,20051209p3608>.

SCIALOM, Melina. Laban Plural: arte do movimento, pesquisa e genealogia da práxis de Rudolf Laban no Brasil. São Paulo: Summus Editorial, 2017.

\section{Sobre os autores}

José Guilherme Bergamasco (Zuza) é mestre em Artes da Cena pela Universidade Estadual de Campinas e graduado em Educação Física pela Pontifícia Universidade Católica de Campinas. Fundou o Espaço Cultural NanoCirco, onde atua como diretor artístico e professor; em 2018 o espaço se tornou Ponto de Cultura. É professor de circo em escolas e em projetos sociais. É integrante do grupo cênico Ponte Pra Lua. Foi professor de Técnicas Circenses do Depto. de Artes Cênicas da UNICAMP de 2012 a 2015. Tem experiência nas áreas de circo, teatro, dança, direção cênica, música.

E-mail: josebergamasco1983@gmail.com.

Veronica Fabrini é Bacharel em Artes Cênicas e Mestre em Artes pela Universidade Estadual de Campinas, Doutora em Artes Cênicas pela Universidade de São Paulo, com pós doutorado em Filosofia e Teatro pelo Centro de Filosofia das Ciências da Universidade de Lisboa. É professora/pesquisadora do Instituto de Artes da Unicamp, membro dos Grupos de Pesquisa Pindorama (Unicamp) e Íman: Imagem e Mito nas Artes da Cena (UFG). É fundadora e diretora artística da Boa Companhia, e atriz. Suas investigações transitam pelos estudos feministas, decoloniais e imaginário.

E-mail: vefabrini@gmail.com. 